\title{
Device Difficult to Operate
}

National Cancer Institute

\section{Source}

National Cancer Institute. Device Difficult to Operate. NCI Thesaurus. Code C91870.

Problems including set-up, operation, and disassembly of equipment. Not including reprocessing. 